Special Section: The economies, ecologies and politics of social forestry in Indonesia Research Article

\title{
What is success? Gaps and trade-offs in assessing the performance of traditional social forestry systems in Indonesia
}

\author{
Indah Waty Bong ${ }^{1, *}$, Moira Moeliono ${ }^{2}$, Grace Yee Wong ${ }^{3}$, Maria Brockhaus ${ }^{4}$ \\ ${ }^{1}$ Center for International Forestry Research (CIFOR), Jalan CIFOR, Situ Gede, Sindang Barang, Bogor Barat \\ 16115, Indonesia. Tel: +622518622622; i.waty@cgiar.org \\ 2 CIFOR, Jalan CIFOR, Situ Gede, Sindang Barang, Bogor Barat 16115, Indonesia. Tel: +622518622622; \\ m.moeliono@cgiar.org \\ 3 Stockholm Resilience Centre, Stockholm University, SE-10691 Stockholm ; grace.wong@su.se \\ 4 Department of Forest Sciences, University of Helsinki, PO Box 27 Helsinki 00014, Finland ; \\ maria.brockhaus@helsinki.fi \\ * Corresponding author
}

\begin{abstract}
Despite the growing interest in social forestry (SF), how much do we understand the social, economic and environmental outcomes and the conditions that enable SF to perform? In this article, we use a content analysis of literature on existing traditional SF practiced throughout Indonesia. It examines the outcomes of these systems and the conditions that enabled or hindered these outcomes to understand possible causal relations and changing dynamics between these conditions and SF performance. We discuss the gaps in how SF is assessed and understood in the literature to understand the important aspects of traditional SF that are not captured or that are lost when the diverse traditional systems are converted into other land uses. It aims to understand the potential trade-offs in the State's push for formalizing SF if these aspects continue to be ignored.
\end{abstract}

Keywords: Traditional social forestry; Indonesia; outcomes; assessment; enabling conditions; gaps and trade-offs.

\section{Introduction}

Forests have long been used and managed by local communities for cultural reasons, subsistence and trade in Indonesia. They modify forests, for example, through their activities of collecting certain species, manipulating forest micro-environments to be favorable to particular species to meet needs at different points in time, and planting valuable species around their settlement. They also protect forests to maintain certain symbolic and sacred sites. The many local practices and management systems have evolved over time to maintain multiple benefits derived from forests and to meet the changing needs of different individuals and groups. While these forms of social forestry have long interacted with trade to meet demand for certain forest products such as rubber and timber, the overwhelming impacts of political change and dominance of markets in recent decades have also led to tensions over access, rights and control of the resources, and differing ideals of developments (Brosius et al., 1998; Moeliono et al., 2017; Peluso and Padoch, 1996). Increasingly, social forestry is being embraced by both the State and rights based organizations as an alternative form of forest management based on ideals of local participation and its potential for poverty alleviation, forest conservation and social justice. More recently, within the climate change agenda, forests are also seen as an important climate mitigation option, with potential benefits for the local community that might come with the capitalization of the services. These ideals are translated into policies promoting social forestry. However, challenges remain in the implementation of the ideals in formal SF programs (Maryudi et al., 2012; Myers et al., 2017). 
With the growing interest in social forestry in Indonesia and elsewhere, we ask to which extent is the expansion of formal social forestry schemes informed by knowledge of existing local practices and the casual relationships between enabling conditions and socio-economic and environmental impacts? For example, Indonesia's ambitious target to allocate 12.7 million hectares of forests to formal SF schemes would also mean that the diverse local practices of forest use and management would be reduced to specific allowable activities regulated under these schemes. What would this mean then for the anticipated outcomes, which were based on experiences observed for different and less restrictive conditions? Already, these formal schemes have been criticized for falling far short of the ideals (Moeliono et al., 2017; Sahide et al., 2016). What are the trade-offs in the State's push for formalizing SF? And in this move, what aspects of traditional SF are missing, 'lost' or ignored - and how would these aspects continue to be ignored when the performance of State formal schemes are evaluated? The local practices of managing forest are shaped by various specific conditions that make the practices and their outcomes different from place to place. Thus, understanding SF performance should focus not only on outcomes but also conditions that enable SF to perform. To do so, we first present a framework adapted from the literature to understand criteria and indicators of SF performance, and how these are assessed in the literature. We then apply the framework to case studies of traditional SF practices in Indonesia.

As there are multiple definitions used to define local practices of managing forest, we refer to a broad definition of social forestry i.e. the management of forests by local communities to achieve various environmental, social and development goals, including climate change mitigation and adaptation, food security, nutrition and livelihood support (Fisher, 1995; Taylor, 2000; Wiersum, 2004). Social forestry would then also include swidden cultivation systems that consist of use and management of natural forests and fallows, and the provision of tree products from a variety of sources and is not limited to tree planting on farms. In this paper, traditional SF refers to the forest management practice that are long practiced and initiated locally by a community to differentiate from formal SF schemes implemented and governed by the State. They are different in terms of objectives and the way forest is managed. Formal SF is introduced by outside parties and usually requires a formal permit, a written management plan and a set of defined objectives and expected outcomes that guide how forest should be managed. While traditional SF is also regulated through the local or customary institutions, the governance of forest use is often adaptive to and evolving with various livelihood, environment, and political dynamics both within and outside community (Wiersum, 1997).

Using our analytical framework, we identify general patterns of similarities and differences in the outcomes of traditional SF systems, and critically assess the conditions that enabled or hindered these outcomes, and attempt to understand possible causal relations between these conditions or characteristics and SF performance. Our study contributes to understanding the complex sociocultural and governance characteristics in diverse traditional SF practices in Indonesia; and to assessing what is gained or lost in the conversion to formal SF schemes advocated by the State.

\section{Analytical framework: understanding success and measuring social forestry outcomes}

The question of what makes social forestry 'successful' is subject to the very definition of success used, which forests is looked at and who constitutes the 'social' in a social forestry scheme, as much as it is influenced by the motivation to conduct such an assessment in the first place. Over the past decades a number of scholars have raised this question in a context where traditional social forestry such as swidden had been illegalized, lacked tenure recognition and was described as causing major deforestation in the tropics (Dove, 1993; Li, 1999; Mertz et al., 2009; Mertz et al., 2005; Moeliono et al., 2017; Peluso et al., 1995; Pham et al., 2018; Thaler and Anandi, 2017). At the same time awareness had increased for the importance of communities in achieving environmental, economic and social sustainability, beyond being simply a target group for top-down planned 
interventions. More studies highlight the positive contributions of traditional and formal social forestry as did investments for example of development organizations in such schemes.

Wollenberg (1998) for example investigated which conditions would enable effective local forest management, finding it most likely to occur when there are high resource potential, viable local social arrangement, and supportive political and economic environment, within a context specific management objective. All of these affect the motivation, resources and capacities of local people to carry out a local forest management practice. Pagdee et al. (2006) in a meta-review of community forestry outcomes highlighted the multidimensional nature of success and the related trade-offs (e.g. increased area under plantation but local needs are no longer covered), indicating that due to these complexities many models remain overly simplified and interdependencies get overlooked. They define CFM's success as outcomes of "ecological sustainability, social equity, and economic efficiency in which objectives for long-term use of the resources are well defined so that expectations of users and the society at large remain consistent". They used the following set measures of success in a meta-analysis, those in bold are the most frequently discussed measures found in the review: 1) Ecological sustainability: improved forest conditions and addressed environment degradation, 2) Equity: enhance equitable sharing of rights and responsibility, improved equitable benefit distribution among community members, and increased investment in future productivity of the forests, and 3) Efficiency: local needs fulfilled, improve living standard, and alleviate poverty, reduce conflicts between communities and authorities, control corruption, resolve mismanagement, reduce individual misuse of the forest. Based on their review nine major factors were identified (three factors in bold are considered specifically important for success):

- Well defined property rights regimes

- Effective institutional arrangements

- Community incentives and interests

- Financial and human resource support

- Physical features of community forests

- Community features

- Level of participation

- Degree of decentralization

- Technology and market influence

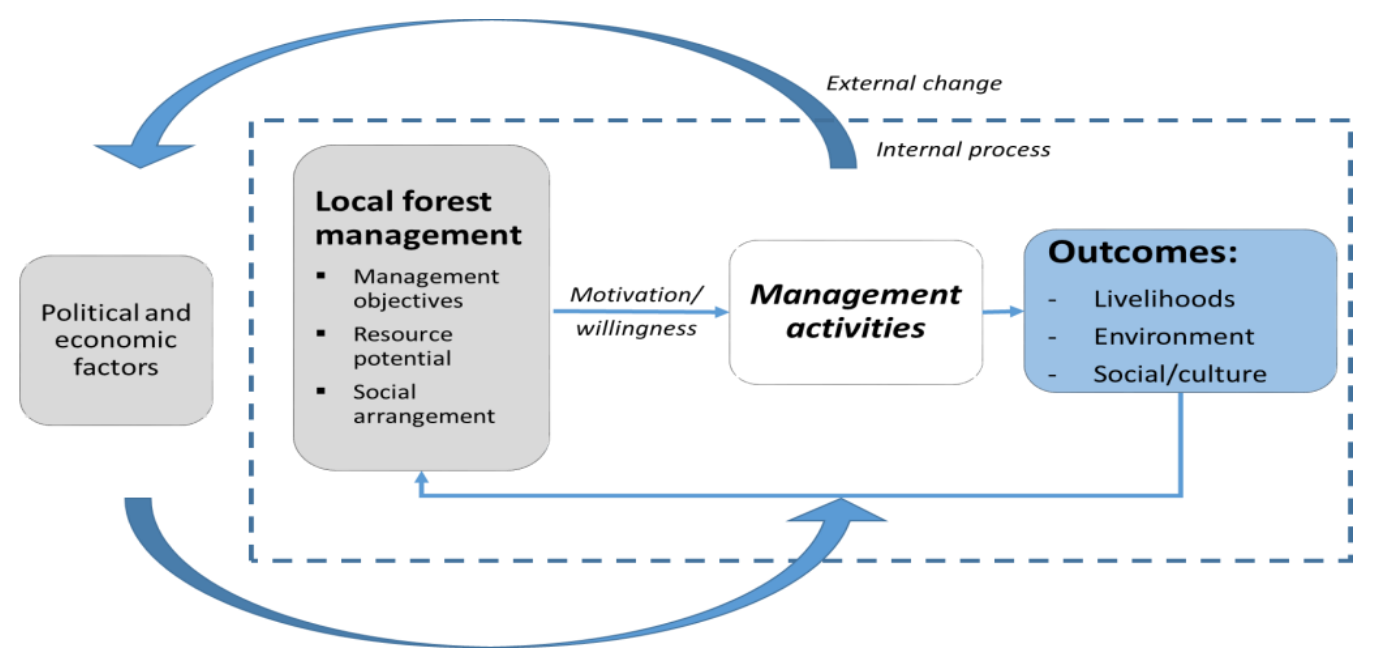

Figure 1. Conditions influencing SF outcomes and their interactions adapted from Wollenberg (1998) . 
Beyond the quest for factors enabling success of the diverse social forestry schemes, the problem of measuring success as pointed out in Pagdee et al. (2006) is further highlighted by Maryudi et al. (2012) in a case study of a formal social forestry scheme in Java. This case highlights the difficulties of measuring success when objectives are not clearly stated, and the indicators remain intangible. Wollenberg (1998) conceptual framework examines the possibility of outcomes from traditional (indigenous or minimal intervention) to formal (introduced) forestry practices. There are conceptual differences between these two types of practices. While objectives of formal SF practices and governance institutions (ways to manage forest and forest use) are stated and written as part of the policy formulation, those of traditional SF are often not explicitly articulated and therefore not formally specified. Local practices may also shift over time to adapt to changing social and environmental conditions, and changing aspirations.

Table 1. Outcomes and conditions influencing outcomes

\begin{tabular}{|c|c|}
\hline OUTCOMES & Definitions \\
\hline $\begin{array}{l}\text { Livelihood } \\
\text { outcome }\end{array}$ & $\begin{array}{l}\text { SF outcome with respect to livelihood objectives (i.e. meet local needs, improve living } \\
\text { standard, food security and alleviate poverty, and improve local adaptive capacity and } \\
\text { resilience) }\end{array}$ \\
\hline $\begin{array}{l}\text { Environment } \\
\text { outcome }\end{array}$ & $\begin{array}{l}\text { SF outcome with respect to environment objectives (i.e. improve/maintain forest } \\
\text { conditions, functions and quality of ecosystem services, and address environmental } \\
\text { degradation }\end{array}$ \\
\hline $\begin{array}{l}\text { Social-cultural } \\
\text { outcome }\end{array}$ & $\begin{array}{l}\text { SF outcomes with respect to social-cultural objectives (i.e. maintain traditional practice, } \\
\text { sense of tradition and identity, customary rules and tradition, and social function/cohesion }\end{array}$ \\
\hline $\begin{array}{l}\text { Political/exter } \\
\text { nal supports }\end{array}$ & $\begin{array}{l}\text { Provide legal basis for forest use and influence local institutional capacity } \\
\text { - } \quad \text { Formal recognition: Issuance of policy/regulation by government supporting the } \\
\text { practice (including allocation of land or forest rights, recognition of local institutions) } \\
\text { - Financial, technical and in-kind supports: Supports from government or external } \\
\text { organizations for better management, product processing and marketing, and } \\
\text { provision of money, inputs, tools and equipment for management practice }\end{array}$ \\
\hline $\begin{array}{l}\text { Economic and } \\
\text { market } \\
\text { influence }\end{array}$ & $\begin{array}{l}\text { Influence local people motivation and capacity to gain benefits from forests. } \\
\text { - Investment/safety net: Practice is considered as investment to land where resources } \\
\text { are kept as assets or saving to be used in times of need } \\
\text { - Access to market/city: In places with better access to market/city, practice is more } \\
\text { intense and aiming at cash products. Practice is oriented to fulfill subsistence needs in } \\
\text { remote places. Remoteness also limits commercialization of resources, keeping } \\
\text { management activities minimum for subsistence } \\
\text { - Livelihood diversity: The availability of other more profitable opportunities often led } \\
\text { people to leave land/forest use related activities or turn their land into agroforest with } \\
\text { low maintenance. Practice can be also secondary activities, people make use times in } \\
\text { between their main activities. It provides an extra source of income }\end{array}$ \\
\hline $\begin{array}{l}\text { Resources } \\
\text { potential }\end{array}$ & $\begin{array}{l}\text { Affect the likely benefits and practices necessary to achieve outcomes. } \\
\text { - Productive potential: Productive capacity of land, soil fertility, favorable plant } \\
\text { characteristics, favorable climate, biological diversity, and forest size } \\
\text { - } \quad \text { Resource pressure: High population density, out-migration, market demand, prices of } \\
\text { forest products } \\
\text { - } \\
\text { Resource stability and resilience: degree to which production or benefits are } \\
\text { maintained despite perturbations, regenerative capacity }\end{array}$ \\
\hline $\begin{array}{l}\text { Local social } \\
\text { arrangements }\end{array}$ & $\begin{array}{l}\text { Determine interactions between individuals or groups and how resource is used. } \\
\text { - Local institutional strength, coherence of interests and incentives: Organizing/ } \\
\text { management capacity, presence of norms/rules, enforcement of rules (through } \\
\text { sanctions/fines), secure property rights, equitable benefit distribution (incentive), } \\
\text { knowledge and technology }\end{array}$ \\
\hline
\end{tabular}


Thus, as part of our analytical framework which guided us through the literature, we analyze the many possible outcomes of traditional SF practices from the multiple livelihood, social, cultural and environment benefits local people obtain from their practice (Table 2). The potential outcomes of SF are based on the broad definition of social forestry that we used in this study and adapting from Maryudi et al. (2012) objective approach, Pagdee et al. (2006) measure of success, and Wollenberg (1998) conceptual framework. These outcomes fall under three broad categories i.e. livelihood, environment/biodiversity, and social/cultural outcomes. We adapt Wollenberg (1998) typology to explain conditions influencing outcomes of SF and the inter-linkages between the enabling conditions (Figure 1 and Table 1).

\section{Methods}

There are two steps in the literature review process. First, a general literature search was conducted in both conceptual and empirical based literature discussing outcomes of SF and factors influencing the outcomes. The result served as a theoretical basis for the paper as presented section 2. Secondly, using the conceptual framework we examined cases of local practices found in the literature. The sources of cases include published reviewed literature, theses, dissertation, and grey literature focusing on traditional social or community forestry practices in Indonesia.

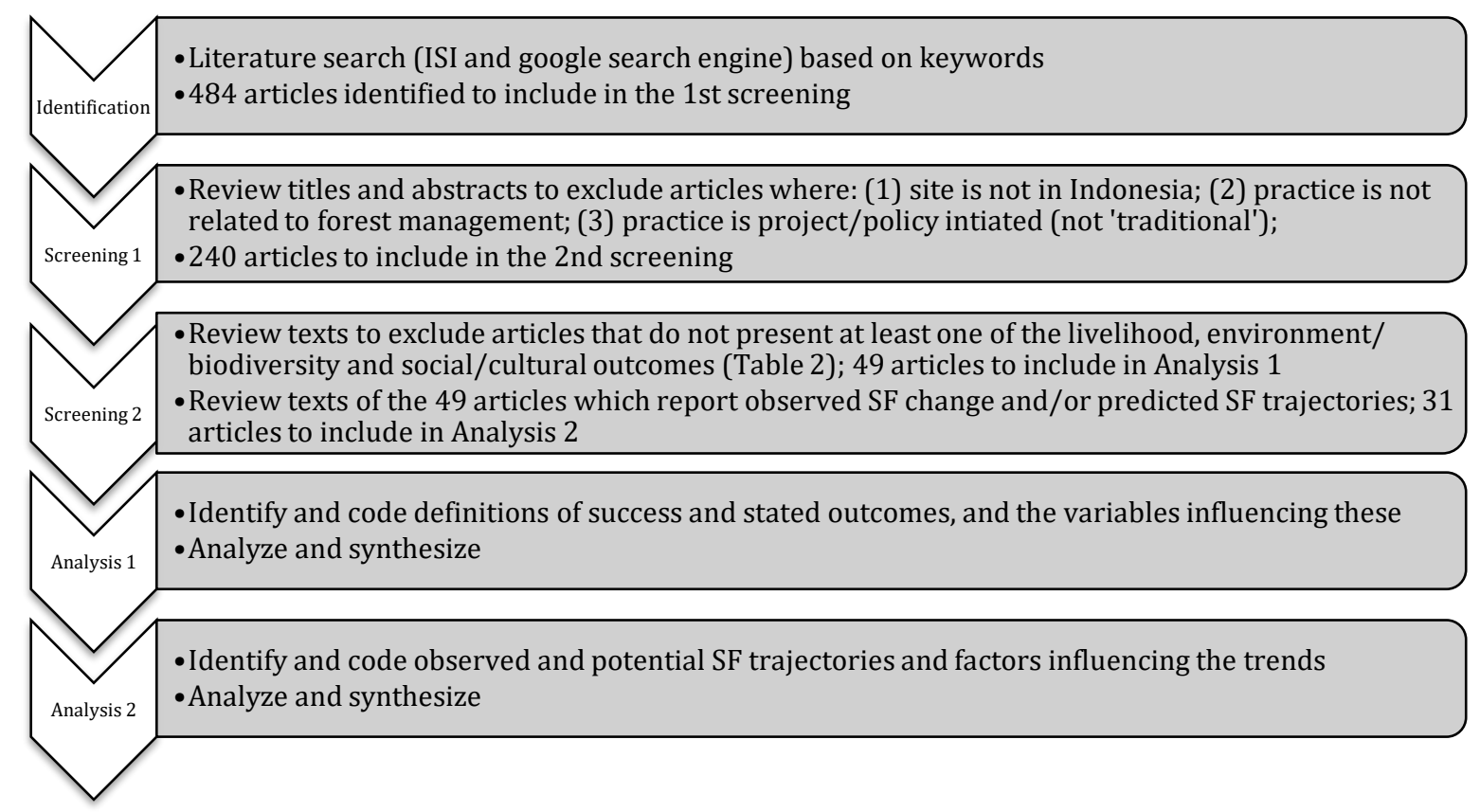

Figure 2. Summary of case selection and review process

We identified traditional social forestry systems using general keywords related to traditional social forestry in both languages, English and Indonesia. The keywords from this exercise are used later to further the literature search of relevant traditional SF practices up to 2016.

General keywords: social forestry, community forest management, village forests, customary forests, perhutanan sosial, hutan masyarakat, hutan adat, hutan sosial, pengelolaan hutan tradisional, hutan masyarakat, shifting cultivation, swidden, fallow, agroforestry, woodlot, forest utilization, traditional forestry, traditional forest practices, forest garden, grove, garden, pertanian tradisional, ladang berpindah, AND Indonesia. 
Additional keywords: tembawang, kaleka, ennungnge, welenrengnge, mangkutta, borong ta'bala, simpuwn, simpukng, pengale, yopomangura, yopomasia, huma, talun, leuweng, dudukuhan, parak, repong, amarasi, mamar, kaliwu, mukim, empus, dusun, taungya, pahewan, limbo, lulic/le'u.

A first screening was carried out to remove articles that are duplicates, practice is not in Indonesia, practice is not related to forest management, and practice is project/policy initiated (not 'traditional SF'). We further reviewed the text of the articles to include only those that present at least one of the livelihood, environment/biodiversity and social/cultural outcomes (Table 1) and narrowed down the articles to 49 cases (see Figure 2 for summary of review process).

\section{Results}

\subsection{Outcomes and their enabling or hindering conditions in traditional social forestry}

\subsubsection{Social forestry outcomes}

All the articles reviewed report to a certain extent SF outcomes (Table 2). One particular outcome reported in all reviewed cases is related to livelihood needs. This includes meeting various cash and subsistence (e.g. food, shelter, medicine, timber, firewood, and art materials) needs, improving local livelihood standards, and alleviating poverty; providing food security (e.g. selfsufficiency of staple food such as upland rice and sago, diverse fruits, animal and edible plants) and forest as an asset and safety net particularly in times of crises. Local practice of forest management is also seen as long-term investment where trees are planted and maintained as living and growing assets to be used in the future either by themselves or by their children, or as a safety net in times of need. For examples, in the Damar agroforest in Sumatra, trees can be pawned when people need money to pay their children schooling (De Foresta et al., 2004). In times of hardship, communities around Lore-Lindu National Park in Central Sulawesi collect substitute foods from forest gardens (e.g. fruits, taro, and sweet potato) (Brodbeck et al., 2003). Other communities reserve land for future agriculture purpose. Until it is needed, land is left to grow into secondary forest or limitedly managed (Gönner and Seeland, 2002).

The second most mentioned outcome is in maintaining environmental functions/biodiversity (86\%). Local people manage their forest in a particular way to maintain its soil fertility (e.g. long rotation swidden-fallow-forest system), or protect a certain forest for its ecosystem service functions (e.g. improve fresh water quality and buffer for drought). These are also related directly to livelihood objectives. Soil fertility is important to ensure productivity of resources while maintaining fresh water and alleviating drought are basic subsistence needs. Some examples include Parak agroforestry system where people maintain some plant species that can improve soil conditions. In swidden systems, farmers leave the land fallow long enough until its soil fertility return and can be used again for cultivation (Suharianto, 2007). In Mamar and Kaliwu systems, layers of canopy is maintained to ensure high litter production that supports conducive micro climate for soil micro-organism to maintain soil fertility. Community also plants mixed of trees and crops to conserve spring for their uses in Mamar system (Njurumana et al., 2008).

Maintaining social/cultural values is another important outcome discussed in $63 \%$ of total reviewed cases. Traditional SF practice is strongly tied to social, culture and belief systems of a community. It maintains local knowledge on valuable species (mainly for medicinal and spiritual purposes), sense of identity, social cohesion (e.g. people can collect fruits from other's garden as long as for own consumption; some SF practices required people to work together because of heavy workload), represent respect to ancestors and nature, maintain customary rules and local institution 
(e.g. related to rights to access and control, lineages and inheritance rights). It includes a holistic view of forest and its resources as integral part of people life and belief system. Rituals and taboos are placed for activities in forest or a certain area of forest or resource that are considered sacred. For instance, the Dayak Benuaq people of Lempunah believe that sacred sites, graveyard, rocks, hills and trees that are commonly found within their simpukng agroforests are inhabited by spirits. Thus they have to be protected and cannot be disturbed. Social function/cohesion as shown by sharing work load/labor and resource exchange/sharing are another value represented by local management practices of forest/forest resources (Setyawan, 2010). Forest might also provide products that are importance for social-cultural events such as betel nut that are associated with rituals of birth, death, courtship and marriage in Serampas and Mamasa communities (Hariyadi, 2008; Millang, 2010).

More than half of reviewed traditional SFs (60\%) discussed all three environment/biodiversity, livelihood and social/culture outcomes collectively as outcomes of SF practices.

Table 2. Frequency of SF outcomes reported in the reviewed literature $(N=49)$

\begin{tabular}{lcc}
\hline SF outcomes & \# of cases & Percentage \\
\hline One outcome reported & & \\
$\quad$ Livelihood & 49 & 100 \\
$\quad$ Environment/Biodiversity & 42 & 86 \\
$\quad$ Social/culture & 31 & 63 \\
\hline Two outcomes reported & & \\
$\quad$ Environment/Biodiversity and Livelihood & 42 & 86 \\
$\quad$ Livelihood and Social/Culture & 31 & 63 \\
$\quad$ Environment/Biodiversity and Social/Culture & 29 & 59 \\
\hline Three outcomes reported & & \\
\hline$\quad$ Environment/Biodiversity, Livelihood, and Social/Culture & 29 & 59 \\
\hline
\end{tabular}

\subsubsection{Factors influencing social forestry outcomes}

Factors associated with local social arrangements are discussed the most as conditions influencing SF outcomes (Table 3). The factors include the following traditional knowledge/practice, tenure and property rights, and customary rules.

\section{Traditional knowledge/practice}

More than half of the reviewed cases describe the significant of existing traditional knowledge that capitalizes in the use and management of forest and forest resources. The geba Bupolo people of Buru Island, Maluku, is one example of how the local people maintain their knowledge and practice of using of plant resources in their daily lives. The use of plants is essential for the geba Bupolo survival as showed by the broad range of knowledge and plant utilization for subsistence (food, house construction, and clothing), domestic and production tools and cultural materials (e.g. weaving, tools for ceremonial and social events, drinks and arts) (Pattinama et al., 2008). In another example within the swidden system, the Dayak people in Kalimantan managed the swidden rice field through a process of planned disturbance based on the local knowledge on forest succession process (Hendra et al., 2009). The land is left fallow for a certain time enough for the soil to recover its fertility. The returned fertility is indicated by different types of successive plants grow on the land. 


\section{Tenure and property rights}

About 35\% of cases discussed "clear ownership" as a factor influencing the success of locally managed forest. In the context of traditional SF, 'clear ownership' refers to informal customary systems of tenure as commonly understood by the community. This factor often mentioned together with customary rules in cases where ownership rights are regulated locally. "Clear ownership" is determined by rights to use, manage, exclude and/or transfer of a resource. The rights include those present on communally owned property where individual rights to use and manage often temporary and limited to personal needs. Clear ownership also includes inalienable inheritance where family owned resource often only transferable through lineage and decision to change land use and practice only can be made through collective agreement.

Table 3. Frequency in discussion of different factors influencing SF outcomes reported in the reviewed literature $(\mathrm{N}=49)$

\begin{tabular}{|c|c|c|}
\hline CONDITIONS influencing outcomes* & \# of cases & Percentage \\
\hline \multicolumn{3}{|l|}{ Political/external supports } \\
\hline 1. Legal recognition & 3 & 6 \\
\hline 2. Financial, technical and in-kind supports & 3 & 6 \\
\hline \multicolumn{3}{|l|}{ Economic and market influence } \\
\hline 3. Investment/safety net & 12 & 24 \\
\hline 4. Access to market/city & 9 & 18 \\
\hline 5. Livelihood diversity & 9 & 18 \\
\hline \multicolumn{3}{|l|}{ Resource potential } \\
\hline 6. Biological diversity & 9 & 18 \\
\hline 7. Tree characteristics & 8 & 16 \\
\hline 8. Elevation/rainfall/climate & 7 & 14 \\
\hline 9. Soil characteristics/fertility & 7 & 14 \\
\hline 10. Population density & 3 & 6 \\
\hline 11. Migration & 1 & 2 \\
\hline 12. Forest size & 1 & 2 \\
\hline \multicolumn{3}{|l|}{ Local social arrangements } \\
\hline 13. Local knowledge & 25 & 51 \\
\hline 14. Clear property rights & 17 & 35 \\
\hline 15. Presence of norms/rules, sanctions/fines & 16 & 32 \\
\hline 16. Organizing/management capacity & 8 & 16 \\
\hline 17. Equity & 3 & 6 \\
\hline
\end{tabular}

*Note: Description on factors is in Table 1

Some examples include the distinctive categories used by Bahau Sa' people for their territory, i.e. village, household and individually owned properties. The village owns the primary forest (tana $\left.t u^{\prime} a n\right) ;$ villagers cannot claim the forestland except for individual trees where private claims are allowed (Nanang and Inoue, 2000). The lulic/le'u sacred grove in West Timor is owned communally, but the rights for hunting and collecting forest foods and materials in the lulic area are regulated by a council of customary elders (McWilliam, 2001). The ownership of Kaleka in Central Kalimantan (Rahu et al., 2014) and damar gardens in Sumatera (De Foresta et al., 2004) within one family are rarely changes. They are passed from one generation to another as a patrimony. 


\section{Customary rules}

The presence of customary rules that govern the use and management of forest and forest resources among community members and groups is discussed in $32 \%$ of cases as an important factor influencing SF outcomes. This factor includes rules that regulate use of forest and forest resources, enforcement of those rules and sanctions/penalties for violating the rules. This factor is often mentioned together with tenure and property rights factors as most customary rules are made to regulate tenure and property rights and social-cultural values in which taboos and spiritual sanctions are placed to enforce the rules.

For instances, in the Parak agroforestry system, the customary rules require people to plant a replacement tree before they cut a tree. The rules also specify types of trees that are protected and cannot be cut such as those that grow on slopes and riverine areas (Suharianto, 2007). Under the mukim customary in Aceh, people's activities in forest area are prohibited in particular days (i.e. every Friday and last Wednesday before the Islamic fasting month) (Syaifuddin et al., 2012). A temporal probation is placed in Nasinoah customary forest in East Nusa Tenggara; the Nasinoah people agreed to not collect forest products from the customary forest for ten years. The rule imposes material sanctions and mystical sanctions that are believed will incur to those who violates the rules (Takandewa, 2012). The Baduy has a complex set of customary rules imposed to maintain their relationship with nature. They use multiple mechanisms to enforce the rules including social control, punishment and self-control mechanism (Ichwandi and Shinohara, 2007).

\subsection{Traditional social forestry: a practice in decline}

Over time, SF systems have evolved in response to various social, economic, and environmental changes and policy events both within and outside the communities. Some local communities have adopted formal SF schemes to gain a legal basis for their traditional practices. In doing so, they have had to adapt their practices and institutional arrangements to meet the formal requirements under a state-initiated SF scheme. Other traditional forms of SF systems are disappearing; fewer people practiced the systems or have converted their forestlands into other land uses. While there are still different SF systems being practiced, these are changing toward more modernized/intensified production practices.

We summarize the observed current changes and potential trajectories of SF and identify causes driving these changes as reported in the reviewed literature. Out of 49 cases, 31 cases report observing current change and/or potential change in the future of SF practice and elaborate the causes of the change (Table 4 and 5).

Various causes were mentioned associated with these changes (Table 5). The causes of change include agricultural expansion (conversion of forests to plantation and cash crop, expansion of agroindustries), agricultural intensification (intensification of land-use, integration of cash crop, shortening fallow period), extractive industries (timber harvesting, mining), exclusion from establishment of state forest/protected area, industry and settlement expansion, and natural disasters (flood, fire, drought). Most cases also elaborated the underlying causes that drive changes in SF practices. These include policy, market and economic, socio-cultural, demographic, and technological and production factors. When a change in SF practice is observed, there is rarely only one single cause driving the change (only 3 cases out of 31 cases associated observed changes with a single cause). The majority of cases mentioned multiple causes that work in complement driving changes in SF and they are highly contextual. Following are two examples of how these causes driving changes in SF practices, the first set of causes are cited most often compare to the second set. 
Table 4. Frequency of different observed and potential SF trajectories stated in the literature

\begin{tabular}{lcc}
\hline SF Trajectories & $\#$ & \% (n=31) \\
\hline Observed current changes & & \\
\hline Disappearing practice (in general) & 11 & 35 \\
Changing towards other land-use systems & 10 & 32 \\
Changing towards intensified/modernized practice & 3 & 10 \\
\hline Predicted changes in the future & & \\
\hline Practice will disappear & 8 & 26 \\
Will change towards other land-use systems & 12 & 39 \\
Will change towards intensified/modernized practice & 7 & 23 \\
\hline Will change towards formalized system & 1 & 3 \\
\hline
\end{tabular}

\section{Market and economy, policy, and agriculture development}

Market and economy, policy and agricultural development are the leading causes driving changes in SF practices. Close access to city/market, increasing demand for cash crops, declining price for SF products and availability of alternative sources of livelihoods are associated with intensification or conversion of land use (Brodbeck et al., 2003; Hariyadi, 2008; Lubis, 1997). Policies drive change in two ways, first by the issuance of regulations that support competing land uses such as agriculture/plantation, mining, concession, and other development programs. This leads to diminishing or conversion of SF to other land uses (Rufinus, 2011). Secondly, through lack of legal recognition or policy supporting SF including acknowledgment of local tenure and institutions. It puts local communities in a weak position to maintain their traditional practices in face of external pressure coming from commercial industrial, agricultural development (Lubis, 1997; Rufinus, 2011)(Marjokorpi and Ruokolainen, 2003) or conservation agenda (De Foresta et al., 2004; Joshi et al., 2004). SF is either disappearing or, in the strategy to seek for legal recognition of rights, adjusted to follow requirements for formalized, state-acknowledged SF schemes such as Community Forest (McWilliam, 2001). Agricultural intensification represents major change of SF towards modernized/production practices. Various cash crop trees such as rubber, cinnamon, albizia, mahogany, banana, and coffee were integrated into the traditional agroforestry system. Swidden farmers also intensified their land practices by shortening the fallow period. The traditional system that was used to mainly serve subsistence function, now is also oriented to provide cash income. Multiple underlying factors drove the intensification process such as increasing needs for cash to pay goods and services, increasing market demand, access to city/market, population growth and favorable pricing policy (Budidarsono et al., 2000; Chen et al., 2010; Hariyadi, 2008; Marjokorpi and Ruokolainen, 2003; Mizuno et al., 2013). 
Table 5. Frequency of factors driving changes of SF practice

\begin{tabular}{|c|c|c|}
\hline & $\begin{array}{l}\text { \# of cases } \\
\text { mentioned }\end{array}$ & Percentage \\
\hline Market and economics & 18 & 58 \\
\hline 1. Access to city/market & 9 & 29 \\
\hline 2. Increasing market demand (inc.higher price of cash crops) & 6 & 19 \\
\hline 3. Increasing needs for cash income & 4 & 13 \\
\hline 4. Declining of market price (for SF product) & 3 & 10 \\
\hline 5. Alternative livelihoods & 2 & 6 \\
\hline $\begin{array}{l}\text { 6. Others (Growing market for land, meeting subsistence, economic } \\
\text { pressure-unspecified) }\end{array}$ & 1 & 3 \\
\hline Policy & 16 & 51 \\
\hline 7. Lack of legal recognition/policy support (inc. local tenure and institutions) & 11 & 35 \\
\hline 8. Policy: agriculture/plantation development & 6 & 19 \\
\hline 9. Policy: mining permit/development & 5 & 16 \\
\hline 10. Policy: establishment of state forest/protected area & 4 & 13 \\
\hline 11. Policy: issuance of logging permit/concessions & 3 & 10 \\
\hline 12. Policy: others (favorable pricing policy, regional development) & 1 & 3 \\
\hline Agricultural expansion & 14 & 45 \\
\hline 13. Conversion to plantation & 8 & 26 \\
\hline 14. Conversion to cash crop & 8 & 26 \\
\hline Agricultural intensification & 10 & 32 \\
\hline 15. Intensification of land-use & 7 & 23 \\
\hline 16. Integration of cash crop trees & 3 & 10 \\
\hline 17. Introduction of technology & 3 & 10 \\
\hline 18. Shortening fallow period & 2 & 7 \\
\hline Extractive industries and industrial expansion & 10 & 32 \\
\hline 19. Timber harvesting & 7 & 23 \\
\hline 20. Mining & 6 & 19 \\
\hline 21. Expansion of industrial areas & 1 & 3 \\
\hline Social-cultural factors & 10 & 32 \\
\hline 22. Weakening local institution & 9 & 29 \\
\hline 23. Degrading traditional knowledge & 5 & 16 \\
\hline 24. Introduction of new value (religion/secular education) & 3 & 10 \\
\hline Demographics & 7 & 23 \\
\hline 25. Population growth & 5 & 16 \\
\hline 26. Expansion of settlement & 2 & 6 \\
\hline 27. Migration & 1 & 3 \\
\hline Disaster & 1 & 3 \\
\hline 28. Disaster (flood, fire, drought) & 1 & 3 \\
\hline
\end{tabular}

Note: Percentages related to the total of all cases that identified changes in SFs ( $N=31)$

\section{Social-cultural factors and demography}

Social-cultural and demographic factors are considered as lesser causes of change in SF practices as compared to other drivers (Table 5). Weakening local institutions, declining traditional knowledge, and introduction of new values (religion and secular educations) are most often been associated with decreasing traditional practice. The younger generation or communities in relatively 
new settlements are considered have lack of knowledge or interests to maintain the traditional practices (Brodbeck et al., 2003). SF practices are also associated with sacralizing of trees or part of forest and traditional belief and ritual that not get along well with modern religions or secular education (Hijjang, 2014; McWilliam, 2001; Setyawan, 2010). In a couple of cases, illegal logging was briefly mentioned as causing high pressure on the existence of forest and threaten the SF practice. It is mentioned in one particular case (Kasepuhan community of East Java) that illegal logging was conducted by some villagers themselves. The activity was stated as a result of weakening role of customary institution and degraded traditional knowledge in combination with increasing needs for cash to procure consumer goods and services (Hendarti and Yeo-Chang, 2008). Increasing population growth was reported in the upper Citarum Watershed as reason for people to convert their kebon-tatangkalan agroforest to cash crop (Parikesit et al., 2005). Increasing population is also linked to industry and settlement expansion in fewer cases (Christanty, 1989; De Foresta et al., 2004).

In Mukim forest, Aceh, both weakening local institution and lack of legal recognition/policy support were reported together as causes of declining local practice. All local institutions throughout Indonesia were diminished during the 30 years of New Order regime (1960s-1990s) including Mukim institution. They were replaced by a uniform structure of village government system imposed by the central government. Communities to certain extent maintain their local institutions informally, but the knowledge and function were significantly weakened. Recently, there was an attempt to revive Mukim forest and institution, however the institutional knowledge on Mukim forest is yet to be revitalized. On other hand, the local institution functions and scope are also not fully acknowledged yet by the state (Syaifuddin et al., 2012).

\section{Discussion}

\subsection{Conversion towards formal social forestry: the trade-offs}

Traditional SF in Indonesia is a declining practice as forests are increasingly converted to agriculture and other land uses, diverse forest practices shift toward more intensified production systems, and traditional systems move towards formal SF schemes. As shown in results, a consequence of the conversion and intensification of local forest and land uses have led to the dominance of monoculture cropping or plantations, and simplified forest structures at the expense of a diversified forest ecosystem.

The trade-off in shifts from traditional to formal SF schemes is the gain of relative tenure security at the expense of social institutions in forest governance. The results show that local institutions and social arrangements are key enabling factors to achieve SF outcomes. However, formulation of policies to devolve forest management through formal schemes often neglects these varied, complex local institutions, resulting in homogenous and rigid policy instruments that undermine the existing, working local arrangements (Fisher et al., 2018; Kamoto et al., 2013; Moeliono et al., 2017). For instance, based on Minister of Environment and Forestry Decree P.83/2016 on Social Forestry and P.11 2016 on Guideline for Verification of Village Forest Management Rights, village forest permit application requires specific institutional arrangements (i.e. in a form of village cooperative or village-owned business). While on the ground, as shown in the review results, local/customary arrangements have fulfilled a similar function of regulating the use and management of local forest in a more adaptive manner.

The relative tenure security in formal SF schemes can also be problematic as it might result in the exclusion of some groups of community. As the State imposes control over forests, the rights to forest are granted to groups or community as regulated within the respective schemes and are often limited to use rights and are time-bound. For example, under the Minister of Environment and Forestry Decree P.83/2016, rights for Community Forestry (HKm) in protected forest is limited to 
collection of non-timber forest products The risk for exclusion, arises from policy instruments enforcing inequity and lack of fairness that are intrinsic in poorly governed forests (Gritten et al., 2015; Kamoto et al., 2013; Larson et al., 2010; Larson and Ribot, 2007). The findings also show that people manage and use forest for multiple outcomes particularly for various cash and subsistence needs (Table 2). The conversion of forests into other land uses and shift from SF towards more intensified production system are mostly motivated by similar livelihood objectives. While formal SF schemes that are focused on entrepreneurial systems, i.e. SF scheme through cooperative or village owned enterprise (BUMDes), can provide more forest-related incomes and livelihood outcomes, the close integration with a market economy has also shown to both increase the vulnerability to fluctuating prices and facilitate declines in SF (see Table 5). In addition, challenges remain in terms of aligning objectives and management of village level business units and SF, and in ensuring equitable benefits for the forest community (De Royer et al., 2018; Fisher et al., 2018).

\subsection{Multidimensionality of social forestry outcomes}

The outcomes of traditional SF are varied and the objectives are not defined in a written form as part of management plan such as in formal SF. The review has shown that local community manage their forests to meet diverse environment, social and livelihood needs in a highly dynamic manner. While the results from the reviewed literature in Table 3 seem to suggest that one outcome (i.e. meeting livelihood needs) is more prominent than others (i.e. maintain environment/biodiversity functions and social/cultural values), this may be a function of the fields of study. What is normally observable and easily measurable are related to incomes and livelihoods. However, the enabling factors for traditional SF strongly leans towards social-cultural arrangements and local institutions, such as traditional knowledge/practice, customary systems of tenure, and customary rules. This highlights the complexity of contexts and history in traditional SF systems and their problematic exclusion from formal SF schemes.

Understanding the performance of a traditional SF practice will require multidisciplinary approaches that look beyond measurable, direct outcomes to include intangible, qualitative outcomes. Livelihood outcomes such as cash incomes can be measured in terms of monetary values but food security, income security over generations and flexibility to respond to crises and opportunity gained from forests are not always easily translated into single measurable indicators. Environmental outcomes in terms of forest cover change, tree density and carbon stock can be quantitatively measured, but environmental services such as regulation of micro-climate and water quality are fuzzier. Social and cultural outcomes are more challenging to measure; as social values, cultural wellbeing, autonomy and identity as farmer or a customary group are non-tangible attributes and change over time. These values often do not fit into the policy evaluation language and 'scientific' categories. Moreover, SF performance is not a case of simply adding up multiple outcomes, as they may not always be separable in the different categories. If the studies reviewed here were not well posed to probe for these values or meaning, this demonstrates how then performance measurements of SF would tend to ignore these complexities.

\subsection{Gaps in SF assessment}

In doing this review, we find three glaring gaps in the literature in how SF is assessed and understood. The first gap is the lack of discussion on the forest condition. Less than $20 \%$ of the cases studied examine the biophysical conditions of the forest (biological diversity, tree characteristics, elevation/rainfall/climate, soil characteristics/fertility, or forest size). This is problematic as the forest condition is both a desired outcome of SF while at the same time the distinctive biophysical factors of a forest may reflect and influence certain SF practices and their outcomes. The practices in using and managing forest by the local people is adjusted to make the best use out of the biophysical conditions, which are also known to influence specific cultural and spiritual practices. 
Understanding the biophysical conditions is of particular interest in the context of environmental change and changing environmental values as they shape SF practices. Persistent climate related issues such as drought and fires, for example, will have significant impact on forest structure (Dale et al., 2001). Drought or fire-resistant plants will thrive while others will lose their regeneration ability, and requires local people to adjust their management practice (Millar et al., 2007). Increasing forest value for its ecosystem service function is yet another external intervention into the way forest is managed at local level. To what extent this change affects local forest management and how the SF system adapts to the change remains a question for further study.

A second and perhaps more critical gap in the case studies is the lack of discussion on social equity and participation. In contrast to findings from studies on community forestry on the importance of equity and inclusive participation as critical success factors (Agarwal, 2001, 2009; Agrawal and Chhatre, 2006; Baland and Platteau, 1999; Maskey et al., 2006; Torpey-Saboe et al., 2015), relatively few cases in this review discussed them explicitly as factors influencing SF outcomes. Participation is mentioned in the context of rights and customary rules. When a SF is practiced on a communal property, while the extent of access might be limited as regulated by the local rules (e.g. only for own use, not for selling purpose), all villagers have access to the resource. In SFs practiced on individual or family owned land (private owned), participation is not relevant (except within family members). In this context, the power dynamics (gender dominance, cross generation hierarchy and inheritance entitlement) influence the extent of participation within family members. When others are allowed to access a certain resource in a privately owned land, it is seen as part of social function/cohesion in which resource are shared to others who are in need. It might be also part of the local customary arrangement where individual's access to a certain resource in private land is allowed as long as not for selling purpose.

Local communities retain traditional knowledge through governance institutions, rules, and practice of using and managing forest to sustain the cultural, livelihood and environmental benefits. Maintaining cultural practices and customary rules in traditional forestry may not always be equitable for women, for example, as existing rules are often male-centered (Agarwal, 1997; Colfer et al., 2015). These knowledge, practices, values, and institutions have evolved in response to changing economic, environmental and sociopolitical conditions. Thus these factors may be key in determining SF performance if empowerment and social equity are desired outcomes.

A third gap relates to local agency in the trajectories of SF change. Market, policy and agriculture development are most frequently reported as drivers of SF change in the literature relative to socio-cultural and demographic factors. The findings emphasize that external forces are often perceived as main drivers of change, while the nuance of interests and perceptions at local level is missing from the discussion. Are local people merely recipients of change or subjects of development? This review highlights the bias of these case studies in applying a technocratic approach and ignoring local voices. A growing related body of literature suggests that there are many more stories behind local people's diverse responses and resistance to change, abandonment of old practice, adaptation and absorption of new interventions such as formal social forestry programs or agriculture development (see for example, Haug 2018, Myers and Muhajir 2015, Semedi and Bakker 2014). Unless local agency in considered, the changes expected from externallyimposed SF program will be far from empowering nor will it meet the social and development aspirations of many (Newman and Dale, 2005).

\section{Conclusion}

The trajectory of traditional SF is on declining pathway as land and forest are being converted to other uses due to mainly market and policy influences. As the territorial boundaries between traditional forestry and state forests become fuzzier, a shift towards a formalized SF seems inevitable. While some communities have moved to accept formal SF schemes as a strategic move 
to legalize community use and claims over forest, this is not necessarily a long-term solution. With the exception of Hutan Adat (Customary Forest), formal SF schemes in Indonesia are time-bound, with permits lasting 35 years and extendable. The management and production objectives are similarly bounded to land zoning rules e.g. Community Forest $(\mathrm{HKM})$ within protection forest limits the management and production objectives to utilization of non-timber forest products; with no planting or timber harvesting allowed within the designated forest area (MOEF Decree P.83/2016). While Hutan Adat is the only SF scheme in Indonesia that devolves both management and ownership rights, the process for full recognition, development of guidelines and issuance of claims have been very slow and there is concern that many forest user groups remain excluded from claims to Hutan Adat (Myers et al., 2017).

As the Government of Indonesia (Gol) moves to expand formal SF schemes to meet its 12.7 million hectare target (Dirjen PSKL 2015), the shift towards formal SF schemes currently reflect a one-way path for local practices to adapt. The politics and complexity in the design, bureaucracy and implementation of the Gol's SF initiative is well discussed elsewhere (see, for example, Moeliono et al., 2017; Sahide et al., 2016; Workman et al., 2015). This rapid expansion of formal SF will also likely increase focus on the measurement of the policy performance as part of the Gol evaluation processes. Our review highlights the problematic challenges in measuring success of SF. Firstly, while the formal SF schemes aim to improve forest users' welfare, local empowerment and forest conditions, this win-win-win solution is unlikely given the challenges that come with imbalance power between actors involved (i.e. State and people) (Wollenberg, 1998) and the narrowly defined rights and rules associated with these schemes (Maryudi et al. 2012). As objectives and management arrangements are directed by State interests, as in formal SF schemes, there is a tendency for SF to become merely a way to decentralize the burdens or social costs of forest management to local people without the full suite of benefits (De Royer et al., 2018; Sahide et al., 2016). Both Wollenberg and Pagdee emphasize the important of considering a fair or proportionate distribution of SF outcomes (Pagdee et al., 2006; Wollenberg, 1998). However, it is also important to understand how particular outcomes might be prioritized at the expense of another. Is livelihood and income outcomes more important than that of social cohesion? And is biodiversity and forest conservation more important than poverty alleviation? More importantly, what is fair for whom? And who determines what is fair? Social, economic, political and environmental changes might also affect people's interest, motivation and decisions related to forest and land uses. The flexibility of social arrangements within traditional SF allows for negotiations of outcomes to meet changing needs over time.

Secondly, even though there might be shared immediate objectives between traditional SF and other state-initiated or climate related interventions in maintaining forest, the long term purposes are different. While a well-designed intervention can be introduced with appropriate distribution of benefits, how it fares relative to long-term traditional SF objectives and the distinctive socio-cultural values that underline traditional SF are uncertain. This suggest the importance to first understand and recognize existing traditional practice and institutional arrangements and how they adapt to change. These findings can support for adoption or negotiation of traditional SF practices and institutions within formal initiatives, and allow for more locally appropriate intervention that can be more robust and empowering.

Thirdly, formal and traditional SF conceptualize land- and forest use very differently. A formal SF operates over an area that has clear boundaries and fall under a specific, legally recognized type of forest and land use (for instance, Hutan Desa within an area that is designated as a protected forest) with clear limits of what activities are possible and legal. Contrarily, the use and management of forest resources and land in a traditional SF is seen as part of an integrated system to meet multidimensional outcomes, which can evolve with different needs and in response to changing conditions. These multiplicity approach in traditional SF practices reflect a holistic view of the broader landscape. Thus, any forest management programs that relate to community should be 
developed based on not only forest policy objectives, but also on the different social, economy and cultural goals of the local communities (Wiersum, 1997).

One concrete step to ensure a more nuanced, context-relevant assessment of SF is to integrate multi-dimensional and context specific measures into the overall development of criteria and indicators in an assessment framework. This includes a need to reconcile local knowledge and existing local practices to develop local level measures that can be integrated and contribute to a broader, flexible and adaptive set of criteria and indicators for measuring local forest management success. The methods and lessons learned for application of these have been explored elsewhere (Lynam et al., 2007; Mendoza and Prabhu, 2004; Mendoza and Martins, 2006; Mendoza and Prabhu, 2000, 2003, 2005; Pokharel and Larsen, 2007; Sherry et al., 2005) yet, in the context of Indonesia, more empirical studies are still much needed.

\section{Areas for future research}

Most outcomes of traditional SFs are measured qualitatively either by stating local perceptions or results of observation. This applies to not only social-cultural outcomes but also economic and bio-physical outcomes. There is a tendency of scholars to focus on those success factors that are already widely discussed and fall into preconceptions of what a traditional SF might achieve. There is an urgent need for more objective and holistic assessments that are multidisciplinary and apply mixed methods. This can be done through integrating the multidimensional aspects of outcomes and trade-offs and convergence/reinforcements between outcomes, and structuring qualitative and quantitative measures on SF performance.

Areas for future research should include investigations into the current stage of practice of traditional SF systems to learn how they are adapting and evolving in response to various political, environmental, social and economic changes. The adaptiveness of the SF system is an aspect that is not covered in this review but could provide an insight into how local needs and livelihoods (and thus, "success") are also changing.

Separating SF into traditional and formalized practices is a useful frame for analysis but is also a shortcoming as there are also a variety of practices in between both. There are external supported/initiated SF such as Amarasi model in West Timor that are well integrated into the local customary system. By adjusting the introduced agroforestry model to answer the local needs and social institutions, the initiative is adopted and recognized as an 'indigenous' natural resource management. Other local SF practices have been practiced for a long time until it was recognized by the government such as Special Assigned Area Repong Damar (Kawasan dengan Tujuan Istimewa KDTI, SK Menhut No. 47/Kpts-II/1998)) in Lampung in 1998 and the Community Forestry (Hutan Kemasyarakatan, HKm) in Sulawesi. More recently in 2012, the acknowledgement of customary forest (through the Constitutional Court No. 35 in 2012) indicates legal recognition on community ownership rights over their forest land and forest management practices. This diverse range of practices between formal and traditional SF systems and the dynamic connection with policy realm is also a worthy focus for future studies.

Conflicts of Interest: The authors declare no conflict of interest. The founding sponsors had no role in the design of the study; in the collection, analyses, or interpretation of data; in the writing of the manuscript, and in the decision to publish the results.

\section{Acknowledgement}

This study was conducted under the ASEAN-Swiss Partnership on Social Forestry and Climate Change (ASFCC), funded by the Swiss Agency for Development and Cooperation (SDC) - Switzerland F-07476.03.04 (From evidence to outcomes: Understanding drivers of change to enhance the contribution of social forestry in ASEAN climate change mitigation and adaptation, Contract no: 81048313). 
The research was led by the Centre of International Forestry Research (CIFOR) in collaboration with University of Tanjungpura (UNTAN). We are grateful to the ASEAN Working Group on Social Forestry (AWGSF) and partners for their instrumental support, advice and patience during the course of this research. We also thank the anonymous reviewers for their constructive and very helpful contributions to this paper. Additional funding was provided by the Norwegian Agency for Development Cooperation; the Australian Agency for International Development; the European Union; the International Climate Initiative (IKI) of the German Federal Ministry for the Environment, Nature Conservation, Building and Nuclear Safety (BMUB); the United Kingdom Department for International Development; and the CGIAR Research Program on Forests, Trees and Agroforestry

\section{References}

Agarwal, B. (1997). Environmental action, gender equity and women's participation. Development and change, 28(1), 1-44.doi: https://doi.org/10.1111/1467-7660.00033.

Agarwal, B. (2001). Participatory exclusions, community forestry, and gender: An analysis for South Asia and a conceptual framework. World development, 29(10), 1623-1648. doi: https://doi.org/10.1016/s0305-750x(01)00066-3.

Agarwal, B. (2009). Gender and forest conservation: The impact of women's participation in community forest governance. Ecological economics, 68 (11), 2785-2799. doi: https://doi.org/10.1016/j.ecolecon.2009.04.025.

Agrawal, A., \& Chhatre, A. (2006). Explaining success on the commons: Community forest governance in the Indian Himalaya. World Development, 34(1), 149-166.doi: https://doi.org/10.1016/j.worlddev.2005.07.013.

Baland, J.-M., Platteau, J.-P. (1999). The ambiguous impact of inequality on local resource management. World development 27 (5), 773-788. doi: https://doi.org/10.1016/s0305750x(99)00026-1.

Brodbeck, F., Hapla, F., Mitlöhner, R. (2003). Traditional forest gardens as "safety net" for rural households in Central Sulawesi, Indonesia. In Conference on: Rural Livelihoods, Forests and Biodiversity, Bonn, CIFOR.

Brosius, J.P., Tsing, A.L., Zerner, C. (1998). Representing communities: Histories and politics of community-based natural resource management. Society \& Natural Resources, 11(2), 157168 doi: https://doi.org/10.1080/08941929809381069.

Budidarsono, S., Arifatmi, B., de Foresta, H., Tomich, T.P. (2000). Damar agroforest establishment and sources of livelihood a profitability assessment of damar agroforest system in Krui, Lampung, Sumatra, Indonesia. Southeast Asia policy Research Working Paper, (17).

Chen, B., Nakama, Y., Yogi, T., Ichwandi, I. (2010). Agroforestry by Baduy Community in Banten province, Indonesia. 琉球大学農学部学術報告, 17-30.

Christanty, L. (1989). Analysis of the sustainability and management of the talun-kebun system of West Java, Indonesia (Doctoral dissertation, University of British Columbia).

Colfer, C.J.P., Daro Minarchek, R., Cairns, M., Aier, A., Doolittle, A., Mashman, V., Odame, H.H., Roberts, M., Robinson, K., Van Esterik, P. (2015). Gender analysis: Shifting cultivation and indigenous people, In Shifting Cultivation and Environmental Change: Indigenous people, agriculture and forest conservation. Routledge.

Dale, V.H., Joyce, L.A., McNulty, S., Neilson, R.P., Ayres, M.P., Flannigan, M.D., Hanson, P.J., Irland, L.C., Lugo, A.E., Peterson, C.J. (2001). Climate change and forest disturbances: climate change can affect forests by altering the frequency, intensity, duration, and timing of fire, drought, introduced species, insect and pathogen outbreaks, hurricanes, windstorms, ice storms, or landslides. AIBS Bulletin, 51(9), 723-734.

De Foresta, H., Michon, G., Kusworo, A., Levang, P. (2004). Damar agroforests in Sumatra, Indonesia: domestication of a forest ecosystem through domestication of dipterocarps for resin 
production, In: Forest products, livelihoods and conservation: case studies of non-timber forest product systems. volume 1-Asia. CIFOR, Bogor, Indonesia.

De Royer, S., Van Noordwijk, M., Roshetko, J. (2018). Does community-based forest management in Indonesia devolve social justice or social costs? International Forestry Review, 20(2), 167180. doi: https://doi.org/10.1505/146554818823767609

Dove, M.R. (1993). A revisionist view of tropical deforestation and development. Environmental conservation 20(1), 17-24. doi: https://doi.org/10.1017/s0376892900037188.

Fisher, M., Moeliono, M., Mulyana, A., Yuliani, E., Adriadi, A., Judda, J., Sahide, M. (2018). Assessing the new social forestry project in Indonesia: recognition, livelihood and conservation? International Forestry Review, 20(3), 346-361. doi: https://doi.org/10.1505/146554818824063014.

Fisher, R.J. (1995). Collaborative management of forests for conservation and development. IUCN Gland, Switzerland.

Gönner, C., Seeland, K. (2002). A close-to-nature forest economy adapted to a wider world: a case study of local forest management strategies in East Kalimantan, Indonesia. Journal of Sustainable Forestry, 15(4), 1-26. doi: https://doi.org/10.1300/j091v15n04_01.

Gritten, D., Greijmans, M., Lewis, S., Sokchea, T., Atkinson, J., Quang, T., Poudyal, B., Chapagain, B., Sapkota, L., Mohns, B. (2015). An uneven playing field: regulatory barriers to communities making a living from the timber from their forests-examples from Cambodia, Nepal and Vietnam. Forests, 6(10), 3433-3451. doi: https://doi.org/10.3390/f6103433.

Hariyadi, B. (2008). The entwined tree: Traditional natural resource management of Serampas, Jambi, Indonesia. University of Hawai'i, Honolulu.

Hendarti, L., Yeo-Chang, Y. (2008). Traditional knowledge on forest resource management by Kasepuhan people in the upland area of West Java, Indonesia. IUFRO World Series, 21, 73.

Hendra, M., Guhardja, E., Setiadi, D., Walujo, E.B., Purwanto, Y. (2009). Cultivation practices and knowledge of local rice varieties among Benuaq farmers in Muara Lawa District West Kutai, East Kalimantan-Indonesia. Biodiversitas, 10(2), 98-103.

Hijjang, P. (2014). Pasang dan Kepemimpinan Ammatoa: Memahami Kembali Sistem Kepemimpinan Tradisional Masyarakat Adat dalam Pengelolaan Sumberdaya Hutan di Kajang Sulawesi Selatan. Antropologi Indonesia, 29(3), 255-268. doi: https://doi.org/10.7454/ai.v29i3.3545.

Ichwandi, I., Shinohara, T. (2007). Indigenous practices for use of and managing tropical natural resources: A case study on Baduy community in Banten, Indonesia. Tropics, 16(2), 87-102. doi: https://doi.org/10.3759/tropics.16.87.

Joshi, L., Wijaya, K., Sirait, M., Mulyoutami, E. (2004). Indigenous systems and ecological knowledge among Dayak people in Kutai Barat, East Kalimantan-a preliminary report. ICRAF Southeast Asia Working People.

Kamoto, J., Clarkson, G., Dorward, P., \& Shepherd, D. (2013). Doing more harm than good? Community based natural resource management and the neglect of local institutions in policy development. Land Use Policy, 35, 293-301. doi: https://doi.org/10.1016/j.landusepol.2013.06.002.

Larson, A.M., Barry, D., Dahal, G.R. (2010). Forests for people: Community rights and forest tenure reform. Earthscan. doi: https://doi.org/10.2989/20702620.2010.507467.

Larson, A.M., Ribot, J.C. (2007). The poverty of forestry policy: double standards on an uneven playing field. Sustainability science, 2(2), 189-204. doi: https://doi.org/10.1007/s11625007-0030-0.

Li, T.M. (1999). Marginality, power, and production: Analysing upland transformations. Transforming the Indonesian uplands, 1-44.

Lubis, Z. (1997). Repong Damar: Kajian tentang pengambilan keputusan dalam pengelolaan lahan hutan di Pesisir Krui, Lampung Barat. CIFOR, Bogor, Indonesia. doi: https://doi.org/10.17528/cifor/000080. 
Lynam, T., De Jong, W., Sheil, D., Kusumanto, T., Evans, K. (2007). A review of tools for incorporating community knowledge, preferences, and values into decision making in natural resources management. Ecology and society, 12(1), 5. doi: https://doi.org/10.5751/es-01987-120105.

Marjokorpi, A., \& Ruokolainen, K. (2003). The role of traditional forest gardens in the conservation of tree species in West Kalimantan, Indonesia. Biodiversity \& Conservation, 12(4), 799-822.

Maryudi, A., Devkota, R.R., Schusser, C., Yufanyi, C., Salla, M., Aurenhammer, H., Rotchanaphatharawit, R., Krott, M. (2012). Back to basics: Considerations in evaluating the outcomes of community forestry. Forest Policy and Economics 14(1), 1-5. doi: https://doi.org/10.1016/j.forpol.2011.07.017.

Maskey, V., Gebremedhin, T.G., Dalton, T.J. (2006). Social and cultural determinants of collective management of community forest in Nepal. Journal of forest economics, 11(4), 261-274. doi: https://doi.org/10.1016/j.jfe.2005.10.004.

McWilliam, A. (2001). Prospects for the sacred grove: Valuing lulic forests on Timor. The Asia Pacific Journal of Anthropology 2(2), 89-113. DOI: https://doi.org/10.1080/14442210110001706125.

Mendoza, G., Prabhu, R. (2004). Fuzzy methods for assessing criteria and indicators of sustainable forest management. Ecological Indicators, 3(4), 227-236. doi: https://doi.org/10.1016/j.ecolind.2003.08.001.

Mendoza, G. A., \& Martins, H. (2006). Multi-criteria decision analysis in natural resource management: a critical review of methods and new modelling paradigms. Forest ecology and management, 230(1-3), 1-22.doi: https://doi.org/10.1016/j.foreco.2006.03.023.

Mendoza, G. A., \& Prabhu, R. (2000). Development of a methodology for selecting criteria and indicators of sustainable forest management: a case study on participatory assessment. Environmental management, 26(6), 659-673. doi: https://doi.org/10.1007/s002670010123.

Mendoza, G. A., \& Prabhu, R. (2003). Qualitative multi-criteria approaches to assessing indicators of sustainable forest resource management. Forest ecology and management, 174(1-3), 329343.doi. https://doi.org/10.1016/s0378-1127(02)00044-0.

Mendoza, G. A., \& Prabhu, R. (2005). Combining participatory modeling and multi-criteria analysis for community-based forest management. Forest Ecology and Management, 207(1-2), 145156..doi: https://doi.org/10.1016/j.foreco.2004.10.024.

Mertz, O., Leisz, S.J., Heinimann, A., Rerkasem, K., Dressler, W., Pham, V.C., Vu, K.C., Schmidt-Vogt, D., Colfer, C.J., Epprecht, M. (2009). Who counts? Demography of swidden cultivators in Southeast Asia. Human Ecology, 37(3), 281-289. doi: https://doi.org/10.1007/s10745-0099249-y.

Mertz, O., Wadley, R.L., Christensen, A.E. (2005). Local land use strategies in a globalizing world: Subsistence farming, cash crops and income diversification. Agricultural systems, 85(3), 209215. doi:https://doi.org/10.1016/j.agsy.2005.06.007.

Millang, S. (2010). Struktur, Komposisi, dan Pemilihan Jenis Komponen Sistem Agroforestry Di Desa Makuang, Kabupaten Mamasa. Universitas Hasanuddin, Makassar

Millar, C. I., Stephenson, N. L., \& Stephens, S. L. (2007). Climate change and forests of the future: managing in the face of uncertainty. Ecological applications, 17(8), 2145-2151. doi: https://doi.org/10.1890/06-1715.1.

Mizuno, K., Mugniesyah, S. S., Herianto, A. S., \& Tsujii, H. (2013). Talun-huma, swidden agriculture, and rural economy in West Java, Indonesia. Southeast Asian Studies, 2(2), 351381.doi: https://doi.org/10.20495/seas.2.2_351

Moeliono, M., Thuy, P.T., Waty Bong, I., Wong, G.Y., Brockhaus, M. (2017). Social Forestry-why and for whom? A comparison of policies in Vietnam and Indonesia. Forest and Society, 1(2), 7897. doi: https://doi.org/10.24259/fs.v1i2.2484. 
Myers, R., Intarini, D., Sirait, M.T., Maryudi, A. (2017). Claiming the forest: Inclusions and exclusions under Indonesia's 'new'forest policies on customary forests. Land Use Policy, 66, 205-213. doi: https://doi.org/10.1016/j.landusepol.2017.04.039.

Nanang, M., \& Inoue, M. (2000). Local forest management in Indonesia: a contradiction between national forest policy and reality. International Review for Environmental Strategies, 1(1), 175-191.

Newman, L., Dale, A. (2005). The role of agency in sustainable local community development. Local environment, 10(5), 477-486. doi: https://doi.org/10.1080/13549830500203121.

Njurumana, G.N., Hidayatullah, M., Butarbutar, T. (2008). Kondisi Tanah pada Sistem Kaliwu dan Mamar di Timor dan Sumba. Info Hutan, 5, 45-51.

Pagdee, A., Kim, Y.-s., Daugherty, P. (2006). What makes community forest management successful: a meta-study from community forests throughout the world. Society and Natural Resources, 19(1), 33-52. doi: https://doi.org/10.1080/08941920500323260.

Parikesit, Takeuchi, K., Tsunekawa, A., Abdoellah, O. (2005). Kebon tatangkalan: a disappearing agroforest in the Upper Citarum Watershed, West Java, Indonesia. Agroforestry systems, 63(2), 171-182. doi: https://doi.org/10.1007/bf01846828.

Pattinama, M.M.J., Nanere, M.G., Nsubuga-Kyobe, A. (2008). The Ethnobotany Of Traditional Agriculture And Agroforestry System Of The Geba Bupolo, Buru Island, Maluku, Indonesia.

Peluso, N.L., Padoch, C. (1996). Changing resource rights in managed forests of West Kalimantan. Borneo in transition: people, conservation, and development, 121-136.

Peluso, N. L., Vandergeest, P., \& Potter, L. (1995). Social aspects of forestry in Southeast Asia: a review of postwar trends in the scholarly literature. Journal of Southeast Asian Studies, 26(1), 196-218.doi: https://doi.org/10.1017/s0022463400010584.

Pham, T., Moeliono, M., Wong, G., Brockhaus, M., Le, N. (2018). The politics of swidden: A case study from Nghe An and Son La in Vietnam. Land Use Policy, In Press. doi: https://doi.org/10.1016/j.landusepol.2017.10.057.

Pokharel, R. K., \& Larsen, H. O. (2007). Local vs official criteria and indicators for evaluating community forest management. Forestry, 80(2), 183-192. doi: https://doi.org/10.1093/forestry/cpm005.

Rahu, A. A., Hidayat, K., Ariyadi, M., \& Hakim, L. (2014). Management of Kaleka (traditional gardens) in Dayak community in Kapuas, Central Kalimantan. International Journal of Science and Research, 3(3), 205-210.

Rufinus (2011). Hutan Adat Tomawakang Ompuk Sanjan Menanti Pengakuan, In Kehutanan Masyarakat: Pengalaman dari Lapangan. FKKM, Bogor, pp. 29-44.

Sahide, M. A. K., Supratman, S., Maryudi, A., Kim, Y. S., \& Giessen, L. (2016). Decentralisation policy as recentralisation strategy: forest management units and community forestry in Indonesia. International Forestry Review, 18(1), 78-95.doi: https://doi.org/10.1505/146554816818206168.

Setyawan, A. D. (2010). Biodiversity conservation strategy in a native perspective; case study of shifting cultivation at the Dayaks of Kalimantan. Nusantara Bioscience, 2(2), 97-108. doi: https://doi.org/10.13057/nusbiosci/n020208.

Sherry, E., Halseth, R., Fondahl, G., Karjala, M., \& Leon, B. (2005). Local-level criteria and indicators: an Aboriginal perspective on sustainable forest management. Forestry, 78(5), 513-539. doi: https://doi.org/10.1093/forestry/cpi048.

Suharianto (2007). Penerapan Hukum Adat Dalam Pengelolaan Sistem Agroforestri Parak (Studi Kasus di Kanagarian Koto Malintang Kecamatan Tanjung Raya, Jabupaten Agam Propinsi Sumatera Barat). Universitas Sumatera Utara, Medan.

Syaifuddin, Ibrahim, A., Hadi, S. (2012). Usulan Pengakuan Hutan Mukim di Aceh, Sebuah Pengalaman Praktis, In Kehutanan Masyarakat: Pengalaman dari Lapangan. FKKM, Bogor, pp. 45-64. 
Takandewa, Y. (2012). Mutiara Hijau di Bumi Cendana, Pengelolaan Hutan Adat di Timor Tengah Selatan, In Kehutanan Masyarakat: Pengalaman dari Lapangan. FKKM, Bogor, pp. 3-28.

Taylor, P. L. (2000). Producing more with less? Community forestry in Durango, Mexico in an era of trade liberalization. Rural Sociology, 65(2), 253-274. doi: https://doi.org/10.1111/j.15490831.2000.tb00028.x.

Thaler, G. M., \& Anandi, C. A. M. (2017). Shifting cultivation, contentious land change and forest governance: the politics of swidden in East Kalimantan. The Journal of Peasant Studies, 44(5), 1066-1087. doi: https://doi.org/10.1080/03066150.2016.1243531.

Torpey-Saboe, N., Andersson, K., Mwangi, E., Persha, L., Salk, C., \& Wright, G. (2015). Benefit sharing among local resource users: the role of property rights. World Development, 72, 408418.doi: https://doi.org/10.1016/j.worlddev.2015.03.005.

Wiersum, K. (2004). Social and community forestry, In: Encyclopedia of forest sciences. Elsevier, pp. 1136-1143. doi: https://doi.org/10.1016/b0-12-145160-7/00118-6.

Wiersum, K. F. (1997). Indigenous exploitation and management of tropical forest resources: an evolutionary continuum in forest-people interactions. Agriculture, ecosystems \& environment, 63(1), 1-16.doi: https://doi.org/10.1016/s0167-8809(96)01124-3.

Wollenberg, E. (1998). A conceptual framework and typology for explaining the outcomes of local forest management. Journal of World Forest Resource Management, 9(1), 1-35.

Workman, T., Fischer, M., Mulyana, A., Moeliono, M., Yuliani, L. 2015. Keluar dari sarang singa, masuk ke mulut buaya?: Pelajaran dari mengembangkan kebijakan hutan adat di Bulukumba. World Agroforestry Centre-ICRAF Southeast Asia Regional Office, Bogor, Indonesia 